\title{
Effects of herbage allowance on defoliation patterns of tall- grass prairie
}

\author{
HOLGER P. JENSEN, ROBERT L. GILLEN, AND F. TED MCCOLLUM
}

\section{Abstract}

Few studies have dealt with measuring individual plant defoliations in the context of intensive grazing management. In May, July, and August of 1987 , grazing trials were conducted to quantify the effects of herbage allowance on defoliation patterns of big bluestem [A ndropogon gerardii Vitman], indiangrass [Sorghastrum nutans (L.) Nash], and little bluestem [Schizachyrium scoparium (Michx.) Nash]. Herbage allowances of 10, 20, 30, and $40 \mathrm{~kg}$ AUD $^{-1}$ were replicated twice per trial. Tiller height, relative leaf area removed, and frequency of defoliation were measured every 2 days over 10-day trials. Indiangrass was the most preferred species in all trials. The rate of leaf area removal increased as herbage allowance decreased. Current guidelines which call for rest periods of 30-90 days would result in light to moderate intensity defoliation for indiangrass at all herbage allowances. The maximum percentage of tillers grazed only once per trial ranged from 20 to $98 \%$ depending on herbage allowance, species, and trial. Selectivity between species was reduced by decreasing herbage allowance but this effect was not large until herbage allowance was below 20-25 kg AUD ${ }^{-1}$ and selectivity was never completely removed. Grazing all tillers only once in a grazing period, even within a species, is unlikely in a tallgrass prairie community. Leaf area removal was moderate the first time a tiller was defoliated and severe for later defoliations. The goal of grazing any individual tiller at no greater than moderate intensity within a grazing period would be roughly equivalent to grazing any tiller no more than once. However such a goal would require many tillers to go ungrazed.

Key Words: defoliation frequency, defoliation intensity, rotation graxing

Grazing management research has focused much attention on short duration grazing during the last 10 years. Most of this research has involved comparisons between grazing systems from a vegetation production and animal performance aspect (Denny and Barnes 1977; Hart and Balla 1982; Ralphs et al. 1986; Heitschmidt et al. 1987a, 1987b). Studies of this nature have clearly illustrated the complexity of plant-animal interactions. However, few studies have addressed the more basic aspects of the impact of short duration grazing management on individual plant defoliations, the level at which any vegetation change will be initiated.

Defoliation patterns can be partially characterized by the frequency and intensity of individual plant defoliation. Researchers in Africa and Europe have found defoliation patterns are dependent on factors such as herbage allowance, season of use, tiller morphology and phenology, species selection, and length of the grazing period (Hodgson and Ollerenshaw 1969, Gammon and Roberts 1980, Curll and Wilkins 1982, Barthram and Grant 1984, Tallowin et al. 1986). These studies were conducted with cattle or sheep on native grass or improved pastures. In the U.S. similar

\footnotetext{
Authors are former graduate research assistant and associate professor Agronomy Department; and associate professor, Animal Science Department, Oklahoma State University, Stillwater. Jensen is currently range conservationist, Bureau of Land Management, Miles City Plaza, Miles City, Montana. Direct reprint requests to second author.

Contribution of the Oklahoma Agricultural Experiment Station as Journal Article 5465 .

Manuscript accepted 28 February 1990.
}

studies have been conducted on rangelands in Wyoming, Utah, Texas, and Washington (Briske and Stuth 1982, Hart and Balla 1982, Norton and Johnson 1983, Brown and Stuth 1984, Pierson and Scarnecchia 1987).

The objective of this study was to relate defoliation patterns by beef cattle to herbage allowance on native tallgrass prairie during the growing season. The major underlying question was the extent to which frequency and intensity of defoliation on individual tillers and selectivity between plant species could actually be altered within short grazing periods by manipulating herbage allowance.

\section{Study Area}

The research was conducted in north central Oklahoma, $3 \mathrm{~km}$ northwest of Oklahoma State University, Stillwater. The average annual precipitation is $84 \mathrm{~cm}$ with $75 \%$ falling during the April to October growing season. This region of Oklahoma has a temperate climate with moderately cold winters and hot, relatively dry summers.

The study site was located on a Renfrow silt loam soil with a 3 to 5\% west-facing slope. Renfrow silt loam soil is a fine, mixed, thermic Udertic Paleustoll with a clay subsoil at $30-40 \mathrm{~cm}$ and is classified as a Claypan Prairie range site.

Vegetation composition of the study site during the summer of 1987 consisted of 35\% big bluestem (Andropogon gerardii Vitman), $22 \%$ little bluestem (Schizachyrium scoparium Michx.) Nash), 22\% indiangrass (Sorghastrum nutans (L.) Nash), 10\% switchgrass (Panicum virgatum L.), and $11 \%$ other perennial grasses, annual grasses and forbs. For several years before the study began, the vegetation was harvested for hay in early July. Six weeks before the study began, the site was burned to ensure a uniform level of spring growth.

\section{Materials and Methods}

Three grazing trials, each lasting 10 days, were conducted during the 1987 growing season on the following dates: 15-25 May (Trial 1), 2-12 July (Trial 2), 12-22 August (Trial 3). Four herbage allowances, $10,20,30$, and $40 \mathrm{~kg} \mathrm{AUD}^{-1}$, were replicated twice for a total of 8 pastures per trial. These herbage allowances are similar to those used by Allison et al. (1982), who concluded that decreases in herbage allowance improved forage harvest efficiency and may be linked to the claimed successes realized from short duration grazing systems. At the conclusion of Trial 1 all pastures were mowed to a height of $10 \mathrm{~cm}$ and allowed to regrow until August when the same area was used for Trial 3. Trial 2 was conducted on an area immediately adjacent to Trial 1 .

Herbage allowances were calculated based on standing crop before the trial started. Fifty $0.1-\mathrm{m}^{2}$ plots were clipped at random over the entire study area allotted to a trial and samples were oven dried to a constant weight and averaged. Pasture size was calculated based on forage demand for 3 steers of similar weight for 10 days of grazing, divided by the initial standing crop (Hodgson 1979). Target herbage allowances for Trial 2 were the same as the other trials, but miscalculations of initial standing crop caused the actual pressures to be adjusted downward to $8,16,24$, and $32 \mathrm{~kg}$ 
Table 1. Mean pre-trial and post-trial standing erop (kg DM ha-1) for 3 eraxing trials in 1987.

\begin{tabular}{|c|c|c|c|c|c|}
\hline \multirow{3}{*}{$\begin{array}{l}\text { Month } \\
\text { of } \\
\text { Trial }\end{array}$} & \multirow{3}{*}{$\begin{array}{c}\text { Pre-grazing } \\
\text { Standing } \\
\text { Crop }\end{array}$} & \multicolumn{4}{|c|}{ Post-grazing Standing Crop } \\
\hline & & \multicolumn{4}{|c|}{ Herbage Allowance $\left(\mathrm{kg} \mathrm{AUD}^{-1}\right)$} \\
\hline & & 10 & 20 & 30 & 40 \\
\hline $\begin{array}{l}\text { May } \\
\text { July² } \\
\text { August }\end{array}$ & $\begin{array}{l}1083 \\
2929 \\
4094\end{array}$ & $\begin{array}{l}498^{b 1} \\
586^{c} \\
947^{b}\end{array}$ & $\begin{array}{c}1020^{a} \\
981^{b c} \\
2190^{a b}\end{array}$ & $\begin{array}{l}1076^{\star} \\
2038^{\star} \\
2547^{\star}\end{array}$ & $\begin{array}{l}1146^{\mathrm{a}} \\
1693^{\mathrm{ab}} \\
3077^{\mathrm{a}}\end{array}$ \\
\hline
\end{tabular}

IValues with the same superscript within a row are not significantly different from each other, $P=0.05$.

${ }_{2}^{2}$ Herbage allowances for Trial 2 were 8, 16, 24, and $32 \mathrm{~kg} \mathrm{AUD}^{-1}$.

AUD $^{-1}$. Pasture sizes were $0.20-0.80,0.06-0.24$, and $0.15-0.24$ ha for Trials 1, 2, and 3. A minimum pasture size of 0.15 ha was set for Trial 3 so that tiller sampling transects could be oriented similarly in all pastures. If the calculated pasture size was less than 0.15 ha, additional animals were added to achieve the target herbage allowance. Pastures were constructed using temporary electric fencing materials. Average steer weights were 295,305 , and $350 \mathrm{~kg}$ for Trials 1, 2, and 3. At the end of each trial, standing crop was estimated using $150.1 \mathrm{~m}^{2}$ plots per pasture. Samples were oven dried, weighed and averaged for each pasture. Species composition was measured across the entire study area (all trials) in August using the dry-weight-rank method with $50,0.1 \mathrm{~m}^{2}$ plots.

Tiller measurements were taken every 2 days during each trial. Three permanent $30 \mathrm{~m}$ transects were located in each pasture and 10 tillers of little bluestem, big bluestem, and indiangrass per transect were marked using color-coded wire rings (Gammon and Roberts 1978). Tiller height and the proportion of leaf area removed were used as relative measures of defoliation intensity. Tiller height was measured from the ground to the highest point on a tiller as it was extended upright. A numerical defoliation intensity code, based on a visual estimate of leaf area removed, was recorded with the following scale: (0) no evidence of defoliation; (1) tiller lightly defoliated, majority of leaf area intact; (2) tiller moderately defoliated, about half of leaf area removed; (3) tiller severely defoliated, little or no leaf area left. A high level of consistency was obtained among observers with a short period of training before each trial (i.e., variation was low). The frequency of tiller defoliation was monitored by marking the cut edges of defoliated tillers with latex paint on each day of measurement.

Pastures were arranged in a randomized complete block design with trial and herbage allowance as whole plots and repeated measures on species, day, and trial. Statistical analysis included standard analysis of variance procedures for intensity of defoliation. Because numerous significant interactions were found between experimental factors, regression models were subsequently developed to predict grazing intensity using herbage allowance and day of grazing as independent variables. The initial models were additive polynomial regression equations consisting of linear and quadratic terms for each independent variable plus all interactions between variables. Reduced models were then fit by dropping terms based on the criteria of size of t-statistics for individual terms and effect on mean square error of the model. Models were developed for each species and trial separately. These methods were then used to predict the time within a grazing period when the average defoliation intensity within a species would be moderate.

Chi-square analysis was used for defoliation frequency distributions. As with the intensity analyses, many significant interactions were found. To simplify data presentation and discussion, attention was focused on the percentage of tillers grazed once within a trial. Prediction models were developed for this variable with the same methods used for defoliation intensity. These models were then used to predict the maximum percentage of tillers that could be grazed once and the time within a grazing period when this maximum would occur.

Analysis of variance was used to analyze the combined effects of intensity and frequency of defoliation. Defoliation intensity at the first, second, and third time a tiller was defoliated was contrasted by herbage allowance, species, and trial.

\section{Results and Discussion}

\section{Standing Crop}

Post-grazing standing crop was least affected by herbage allowance in the spring except at the $10 \mathrm{~kg} \mathrm{AUD}^{-1}$ herbage allowance (Table 1). This was likely a result of the rapid growth rate of tillers in May. Post-grazing standing crop decreased as herbage allowance increased during July and August. Reece (1986) reported similar results in Nebraska.

\section{Intensity of Defoliation}

Coefficients of determination for the polynomial regression equations predicting grazing intensity were high (Table 2) and evaluation of the regression statistics and plots of observed versus predicted values indicated the polynomial models were representative of the field data. The general form of the relationship between herbage allowance and grazing intensity is expressed by indiangrass in Trial 1 (Fig. 1). Grazing intensity was generally curvilinear over time, especially at the higher herbage allowances. The curves were well separated between herbage allowances. Across all species and trials, a major separation tended to occur between 20 and $30 \mathrm{~kg}$ AUD $^{-1}$ herbage allowance.

As herbage allowance decreased the time required to reach moderate defoliation decreased for all species during all trials (Fig. 2). Indiangrass was moderately defoliated before the other 2 species in all trials. Big bluestem was only slightly less preferred than indiangrass. Little bluestem was clearly the least preferred of the 3 species. Defoliation intensity was lower during Trial 1 than the

Table 2. Coeficients of polynomial regresion equations for defoliation intensity described as leaf area removal, $\mathbf{N}=$ sample size, $\mathbf{R}^{2}=$ coefficient of determination, $\mathrm{Sy}, \mathrm{x}=$ standard error of the eatimate, $\mathrm{H}=$ herbage allowance, $\mathrm{D}=$ day of prazing. All regreasion terms significant at $P<0.05$.

\begin{tabular}{|c|c|c|c|c|c|c|c|c|c|c|c|c|}
\hline Species & Trial & $\mathbf{N}$ & $\mathbf{R}^{2}$ & $\overline{S_{y, x}}$ & $\begin{array}{c}b_{1} H \\
\left(10^{-1}\right)\end{array}$ & $\begin{array}{l}\mathrm{b}_{2} \mathrm{H}^{2} \\
\left(10^{-3}\right)\end{array}$ & $b_{3} D$ & $\begin{array}{l}b_{4} D^{2} \\
\left(10^{-1}\right)\end{array}$ & $\begin{array}{c}\mathrm{b}_{5} \mathrm{H} \times \mathrm{D} \\
\left(10^{-1}\right)\end{array}$ & $\begin{array}{c}b_{6} \mathrm{H} \times D^{2} \\
\left(10^{-2}\right)\end{array}$ & $\begin{array}{c}\mathrm{b}_{7} \mathrm{H}^{2} \times \mathrm{D} \\
\left(10^{-3}\right)\end{array}$ & $\begin{array}{c}\mathrm{b}_{8} \mathrm{H}^{2} \times \mathrm{D}^{2} \\
\left(10^{-4}\right)\end{array}$ \\
\hline Big bluestem & $\begin{array}{l}1 \\
2 \\
3\end{array}$ & $\begin{array}{l}40 \\
36 \\
38\end{array}$ & $\begin{array}{l}0.97 \\
0.99 \\
0.99\end{array}$ & $\begin{array}{l}0.31 \\
0.25 \\
0.20\end{array}$ & $\begin{array}{c}-0.081 \\
0.35 \\
0.351\end{array}$ & -0.971 & $\begin{array}{l}0.74 \\
0.91 \\
1.45\end{array}$ & $\begin{array}{l}-0.37 \\
-0.60 \\
-1.22\end{array}$ & $\begin{array}{l}-0.16 \\
-0.24 \\
-0.84\end{array}$ & $\begin{array}{l}0.11 \\
0.19 \\
0.82\end{array}$ & 1.49 & -1.44 \\
\hline Indiangrass & $\begin{array}{l}1 \\
2 \\
3\end{array}$ & $\begin{array}{l}40 \\
36 \\
38\end{array}$ & $\begin{array}{l}0.94 \\
0.99 \\
0.99\end{array}$ & $\begin{array}{l}0.48 \\
0.30 \\
0.22\end{array}$ & $\begin{array}{l}0.241 \\
1.001 \\
0.441\end{array}$ & $\begin{array}{l}-1.08^{1} \\
-2.86^{1} \\
-0.97^{1}\end{array}$ & $\begin{array}{l}0.52 \\
1.38 \\
1.80\end{array}$ & $\begin{array}{l}-0.20 \\
-1.17 \\
-0.16\end{array}$ & $\begin{array}{l}-0.94 \\
-1.09\end{array}$ & $\begin{array}{l}0.93 \\
1.10\end{array}$ & $\begin{array}{r}-0.10 \\
2.13 \\
1.87\end{array}$ & $\begin{array}{l}-2.04 \\
-1.86\end{array}$ \\
\hline Little bluestem & $\begin{array}{l}1 \\
2 \\
3\end{array}$ & $\begin{array}{l}40 \\
36 \\
38\end{array}$ & $\begin{array}{l}0.98 \\
0.95 \\
0.97\end{array}$ & $\begin{array}{l}0.20 \\
0.36 \\
0.28\end{array}$ & $\begin{array}{r}-0.09^{1} \\
-0.26^{1} \\
0.26^{1}\end{array}$ & $\begin{array}{l}-0.071 \\
-0.82^{1}\end{array}$ & $\begin{array}{l}0.64 \\
0.60 \\
0.59\end{array}$ & $\begin{array}{l}-0.10 \\
-0.22\end{array}$ & $\begin{array}{l}-0.24 \\
-0.06 \\
-0.25\end{array}$ & & $\begin{array}{l}0.32 \\
0.37\end{array}$ & \\
\hline
\end{tabular}

'Not significant at $P<0.05$, included because higher order interactions were significant. 


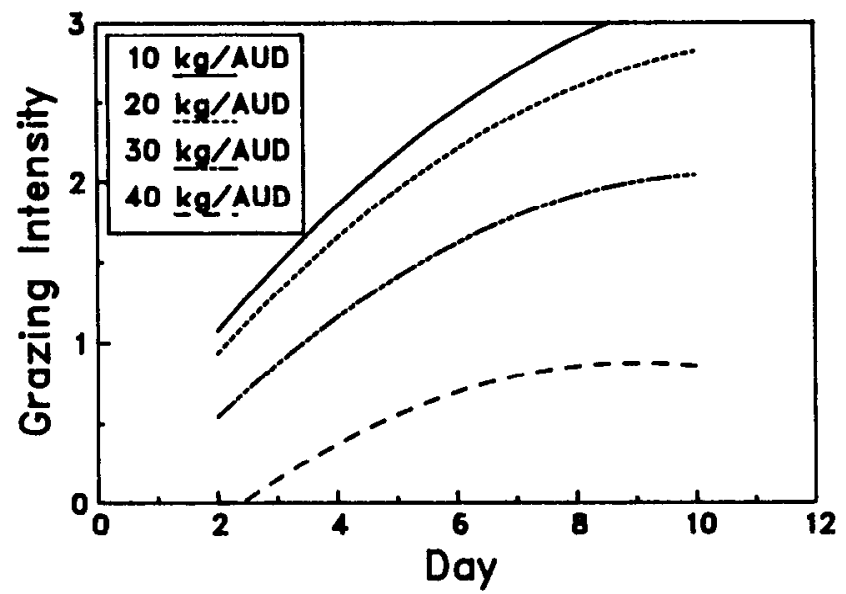

Fig. 1. Defoliation intensity for indiangrass as affected by herbage allowance and day of grazing. Intensity scale: $0=$ undefoliated, $1=$ light, 2 = moderate, 3 = severe. Trial 1, May, 1987.

other 2 trials with no species receiving moderate defoliation within the 10-day trial at herbage allowances above $30 \mathrm{~kg} \mathrm{AUD}^{-1}$. For all 3 trials, little bluestem never reached moderate defoliation at herbage allowances greater than $25 \mathrm{~kg} \mathrm{AUD}^{-1}$. Convergence of the species curves at lower herbage allowances supports the hypothesis of Holmes (1980) that grazing selectivity declines as herbage allowance decreases. However, defoliation intensity of little bluestem lagged 1 to 2 days behind the other species even at the lowest herbage allowances.

Tiller height was inversely related to intensity of defoliation based on the proportion of leaf area removed. Relationships among species, herbage allowances, and trials, relative to tiller height, were similar to those for leaf area removal.

Herbage allowance is greater under continuous grazing compared to multi-pasture grazing systems (Table 3). Moderate stocking for this range site is 1.4 ha per yearling steer $(0.7 \mathrm{AU})$ for 150

Table 3. Herbage allowances (kg AUD-1) within 10 day grazing periods as affected by number of pastures. Based on experimental conditions in 1987 and stocking rate of $1.4 \mathrm{ha} /$ yearling steer/150 days $(0.7$ AU/steer).

\begin{tabular}{lcccc}
\hline \hline & \multicolumn{4}{c}{ Number of Pastures } \\
\cline { 2 - 5 } & 1 & 8 & 16 & 32 \\
\hline May & 214 & 27 & 13 & 7 \\
July & 562 & 70 & 35 & 18 \\
August & 709 & 89 & 44 & 22 \\
\hline
\end{tabular}

days. The range of herbage allowance included in this study is applicable to 16-32 pasture systems at moderate stocking rates, but would also apply to 8 pasture systems if stocking rates were substantially increased.

The regression models and data in Tables 2 and 3 were used to calculate theoretical grazing and resting periods under rotation grazing that would result in moderate utilization of indiangrass, the most palatable species, during each trial period (Table 4). Grazing periods would not change with season in systems with greater numbers of pastures (Table 4). Moderate utilization would not usually be achieved within 10 days with 8 or fewer pastures. Rest periods based on these grazing periods are all greater than 49 days, over two-thirds of the periods are greater than 68 days (Table 4). Rest periods in the 8 and 16 pasture systems are within the range of rests recommended for intensive grazing management (Savory 1988). Rest periods at the 32 pasture level are longer than the maximum recommended rest periods. Grazing cycles could be
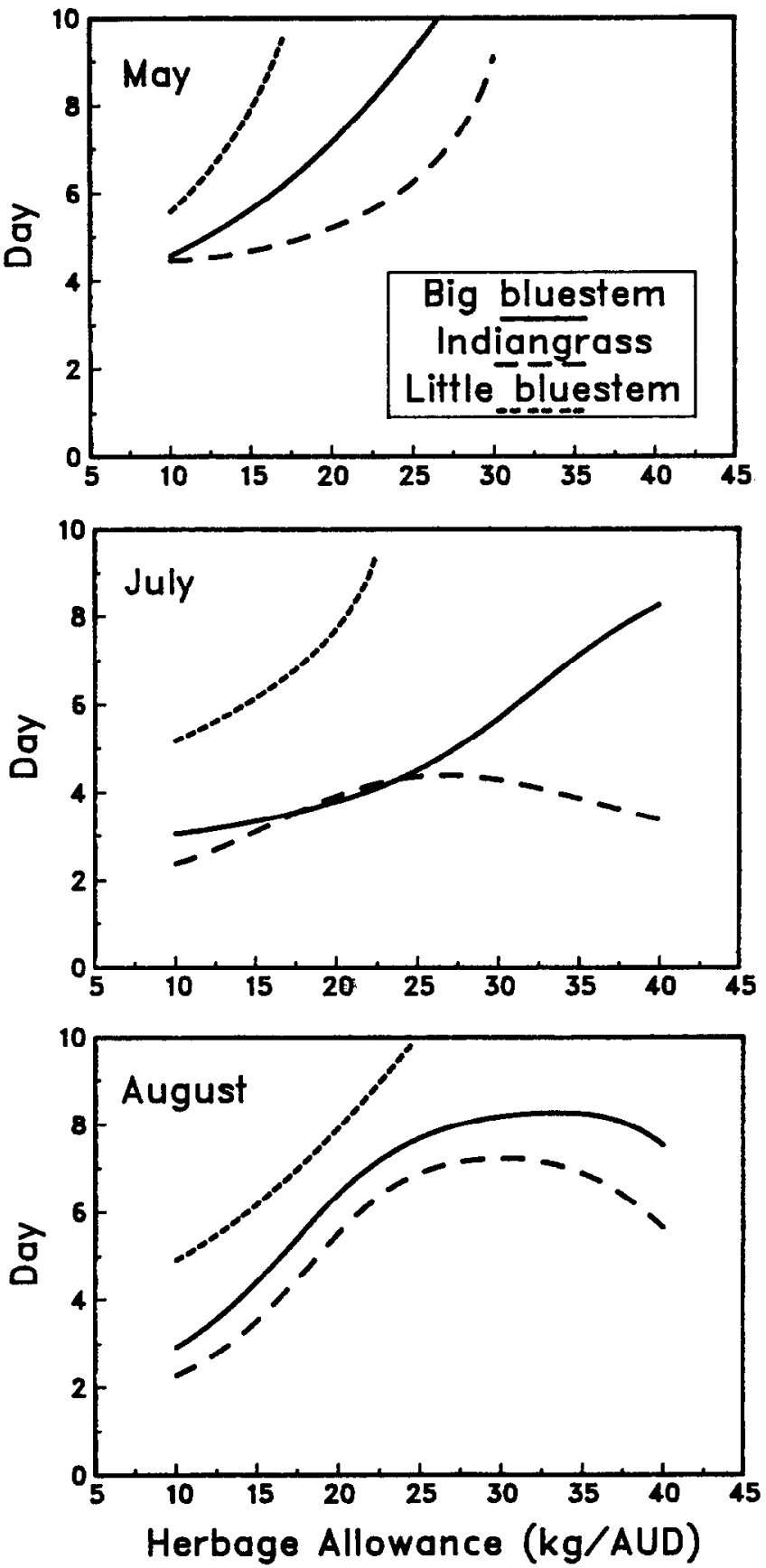

Fig. 2. Time at which moderate utilization was achieved within a trial for 3 grass species.

shortened, especially early in the growing season when plant growth is rapid, which would benefit animal performance (Hart 1989). If grazing periods are based on target rest periods instead of vice versa (Savory 1988), defoliation intensity within the grazing periods would generally be light to moderate.

\section{Frequency of Defoliation}

The general pattern of distribution of tillers among defoliation classes (not grazed, grazed once, grazed twice, ...) is illustrated by big bluestem at the $20 \mathrm{~kg} \mathrm{AUD}^{-1}$ herbage allowance during Trial 1 (Fig. 3). As the trial progressed, the proportion of tillers not grazed or grazed once declined while the proportion grazed twice or more increased. Tillers were not concentrated into a single frequency class. At least $20 \%$ of the tillers were present in 2 or more frequency classes. Gammon (1984) also concluded some tillers receive multi- 
Table 4. Grazing and rest periods to produce moderate intensity defoliation on indiangrass as affected by number of pastures. Based on experimental conditions in 1987 and a stocking rate of $1.4 \mathrm{ha} /$ yearling steer $(0.7$ AU).

\begin{tabular}{lcccccccc}
\hline \hline & \multicolumn{3}{c}{ Days of Grazing } & & \multicolumn{3}{c}{ Days of Rest } \\
\cline { 2 - 4 } \cline { 7 - 8 } \cline { 6 - 8 } Month & \multicolumn{3}{c}{ Number of Pastures } & & \multicolumn{3}{c}{ Number of Pastures } \\
\cline { 2 - 4 } \cline { 6 - 8 } May & 8 & 16 & 32 & & 8 & 16 & 32 \\
July & 7 & 4.5 & 4.5 & & 49 & 68 & 140 \\
August & $>10$ & 4.0 & 3.5 & & $>70$ & 60 & 109 \\
\hline
\end{tabular}

ple defoliations even at low herbage allowances.

Coefficients of determination for the polynomial regression equations predicting the percentage of tillers grazed once ranged from 0.59 to 0.88 with only 1 coefficient below 0.72 (Table 5). These values are lower than those from the grazing intensity models. Evaluation of plots of observed versus predicted values indicated that much of the variation not accounted for by the models was attributable to variation between replications. The polynomial models adequately represented the relationships between herbage allowance and percentage of tillers grazed once.

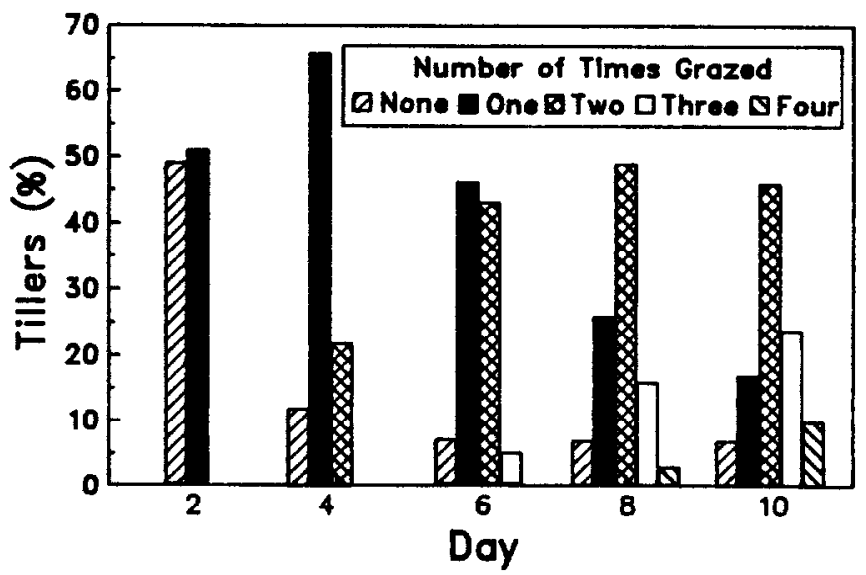

Fig. 3. Defoliation frequency distributions for big bluestem at a herbage allowance of $20 \mathrm{~kg} \mathrm{AUD}^{-1}$. Trial 3, August, 1987.

A common objective of short duration grazing is to defoliate all tillers in a pasture once during a grazing period. This objective was clearly impossible to achieve during May (Trial 1) because no more than $60 \%$ of the tillers were in the grazed once frequency class on any day regardless of herbage allowance or species (Fig. 4). The maximum percentage of tillers that were grazed once did increase
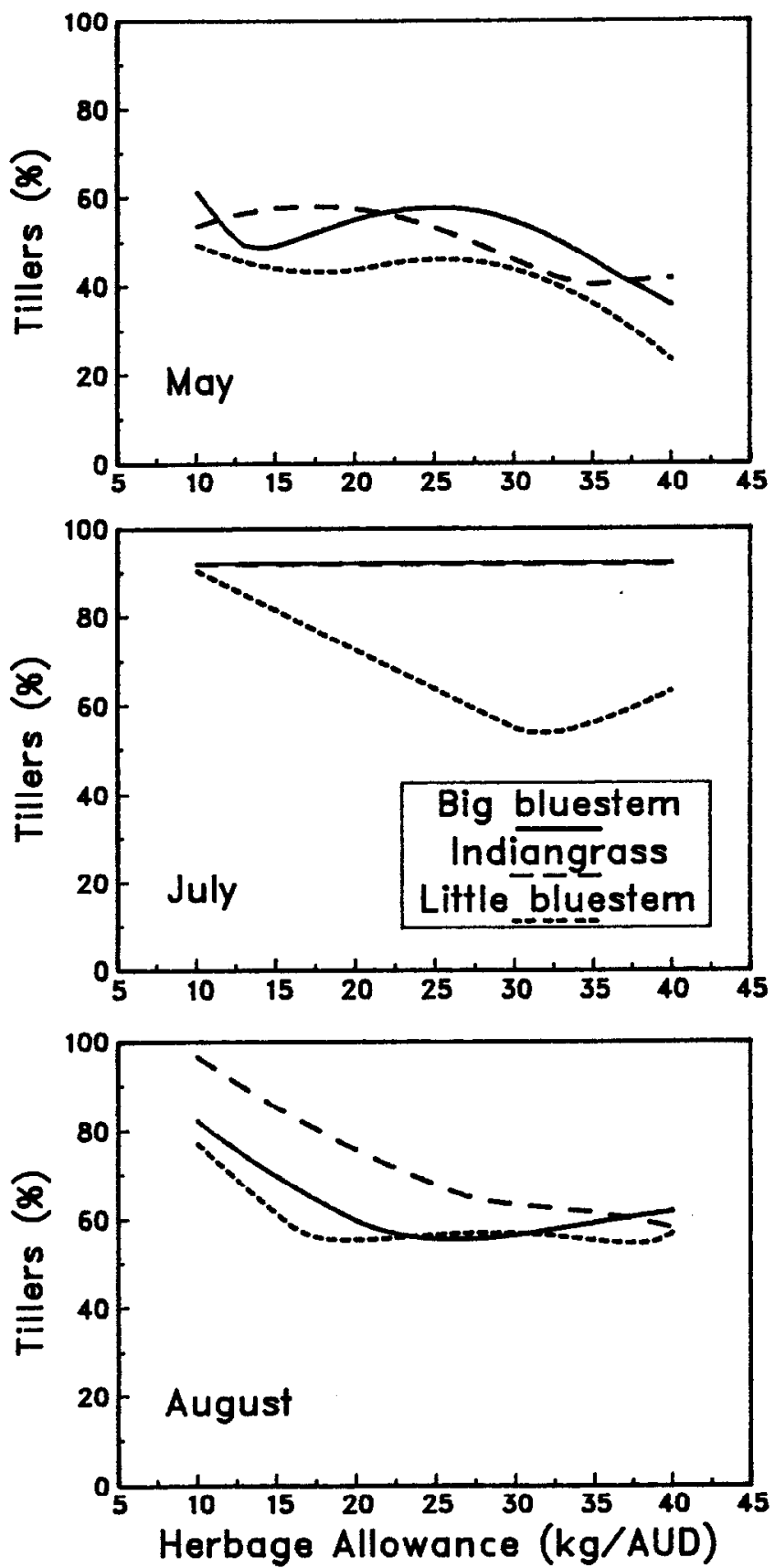

Fis. 4. Maximum percentage of tillers grazed once within a trial for 3 grass species.

Table 5. Coefficients of polynomial regrescion equations for percentage of tillers grazed once, $N=$ sample size, $R^{2}=$ coeficient of determination, Sy, $x=$ standard error of the estimate, $\mathbf{H}=$ herbage allowance, $D=$ day of graxing trial. All regression terms significant at $P<0.05$.

\begin{tabular}{|c|c|c|c|c|c|c|c|c|c|c|c|c|c|}
\hline Species & Trial & $\mathbf{N}$ & $\mathbf{R}^{2}$ & $S_{y x}$ & $b_{0}$ & $\begin{array}{l}b_{1} H \\
\left(10^{1}\right)\end{array}$ & $\begin{array}{l}b_{2} H^{2} \\
\left(10^{-1}\right)\end{array}$ & $\begin{array}{l}b_{3} D \\
\left(10^{2}\right)\end{array}$ & $b_{4} D^{2}$ & $b_{8} H \times D$ & $\begin{array}{c}\mathrm{b}_{6} \mathrm{H} \times \mathrm{D}^{2} \\
\left(10^{-1}\right)\end{array}$ & $\begin{array}{c}\mathrm{b}_{7} \mathrm{H}^{2} \times \mathbf{D} \\
\left(10^{-1}\right)\end{array}$ & $\begin{array}{c}\mathrm{b}_{8} \mathrm{H}^{2} \times \mathrm{D}^{2} \\
\left(10^{-1}\right)\end{array}$ \\
\hline Big bluestem & $\begin{array}{l}1 \\
2 \\
3\end{array}$ & $\begin{array}{l}40 \\
34 \\
38\end{array}$ & $\begin{array}{l}0.85 \\
0.87 \\
0.77\end{array}$ & $\begin{array}{r}8.42 \\
12.37 \\
9.32\end{array}$ & $\begin{array}{l}209 \\
177 \\
150\end{array}$ & $\begin{array}{r}-1.64 \\
-0.63\end{array}$ & $\begin{array}{l}2.76 \\
0.84\end{array}$ & $\begin{array}{l}-5.14 \\
-3.34 \\
-1.58\end{array}$ & $\begin{array}{r}2.62 \\
1.69 \\
-0.68\end{array}$ & $\begin{array}{l}5.65 \\
1.25\end{array}$ & -3.39 & $\begin{array}{l}-1.06 \\
-0.16\end{array}$ & 6.78 \\
\hline Indiangrass & $\begin{array}{l}1 \\
2 \\
3\end{array}$ & $\begin{array}{l}40 \\
36 \\
38\end{array}$ & $\begin{array}{l}0.59 \\
0.88 \\
0.86\end{array}$ & $\begin{array}{r}14.05 \\
12.00 \\
9.45\end{array}$ & $\begin{array}{r}24 \\
187 \\
275\end{array}$ & $\begin{array}{r}0.31 \\
-1.24\end{array}$ & $\begin{array}{r}-0.97 \\
1.66\end{array}$ & $\begin{array}{c}0.581 \\
-3.81 \\
-8.89\end{array}$ & $\begin{array}{r}-1.05 \\
2.07 \\
6.70\end{array}$ & 5.61 & -4.72 & -0.81 & $\begin{array}{l}0.60 \\
7.23\end{array}$ \\
\hline $\begin{array}{l}\text { Little } \\
\text { bluestem }\end{array}$ & $\begin{array}{l}1 \\
2 \\
3\end{array}$ & $\begin{array}{l}37 \\
37 \\
37\end{array}$ & $\begin{array}{l}0.72 \\
0.86 \\
0.78\end{array}$ & $\begin{array}{l}9.23 \\
7.94 \\
9.75\end{array}$ & $\begin{array}{r}62 \\
258 \\
211\end{array}$ & $\begin{array}{r}-0.36 \\
-0.69 \\
-1.26\end{array}$ & $\begin{array}{l}0.381 \\
1.78\end{array}$ & $\begin{array}{r}0.87 \\
-5.95 \\
-5.41\end{array}$ & $\begin{array}{r}-1.68 \\
3.17 \\
3.151\end{array}$ & $\begin{array}{l}2.09 \\
4.86\end{array}$ & $\begin{array}{r}0.88 \\
-1.23 \\
-3.44\end{array}$ & -0.80 & $\begin{array}{r}-1.42 \\
6.26\end{array}$ \\
\hline
\end{tabular}

'Not significant at $P<0.05$, included because higher order interactions were significant. 

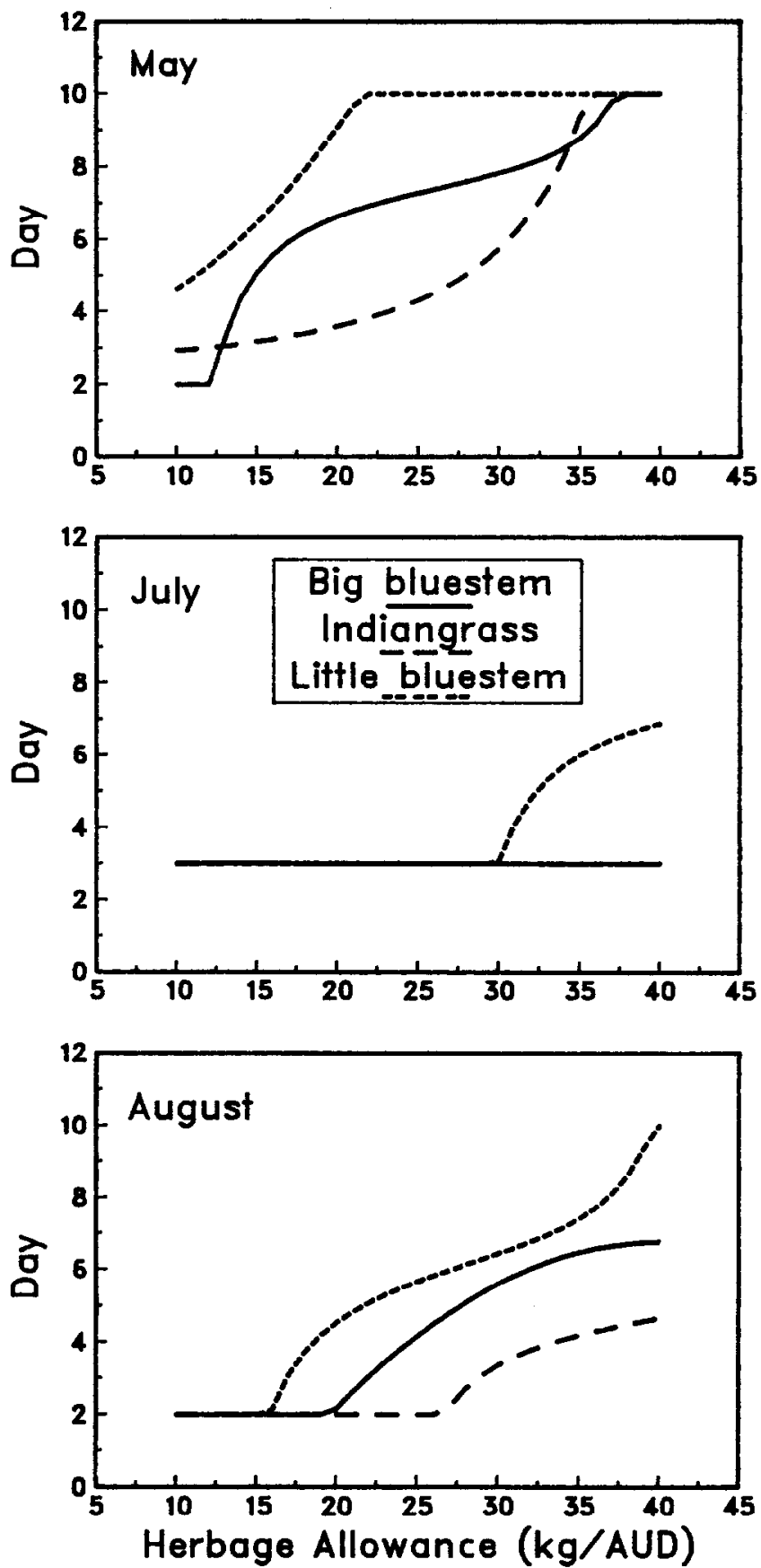

Fig. 5. Time at which maximum percentage of tillers grazed once within a trial was achieved for 3 grass species.

slightly as herbage allowance decreased. Herbage allowance did not affect the maximum percentage grazed once for indiangrass and big bluestem in July (Trial 2). This outcome is likely a sampling artifact. Heavy rainfall prevented sampling of the marked tillers until Day 3 of Trial 2 compared to the normally planned sampling on Day 2. Some regrazing had probably occurred by Day 3, especially at the lower herbage allowances, so the percentage of tillers in the grazed once class probably included some tillers grazed twice. The maximum percentage of tillers grazed once was only sensitive to herbage allowance below $20-25 \mathrm{~kg} \mathrm{AUD}^{-1}$ in August (Trial 3).

Grazing selectivity within plant species was reduced as the season progressed. On average, the maximum percentage of tillers grazed once increased in July and August compared to May (Fig. 4). Plant growth was most rapid during May. Regrowth may have been occurring rapidly enough to attract the cattle back to previously grazed tillers. In the later trials, tillers were growing more slowly so the livestock had to seek greater numbers of tillers.

The maximum percentage of tillers grazed once was reached more rapidly as herbage allowance declined (Fig. 5). The major exception to this pattern occurred for indiangrass and big bluestem in July (Trial 2) when the maximum was reached on Day 3 for all herbage allowances. As previously discussed, Day 3 was the first day of sampling during Trial 2 and regrazing had probably already taken place by that time.

These data indicate livestock should be moved more rapidly as herbage allowance decreases because the point at which the percentage of tillers grazed once is maximized occurs earlier. However, this percentage will seldom reach the theoretical goal of $100 \%$. A range of $60-80 \%$ may be all that is practically attainable. Selectivity for tillers within species will still occur. Selectivity among species will also be present because the maximum percentage of tillers grazed once did not occur on the same day for all species. Little convergence of the species curves occurred until herbage allowance was reduced below $20-30 \mathrm{~kg} \mathrm{AUD}^{-1}$.

\section{Intensity and Frequency of Defoliation}

The intensity of defoliation, in terms of proportion of leaf area removed, increased with each defoliation (Fig. 6). Intensity was

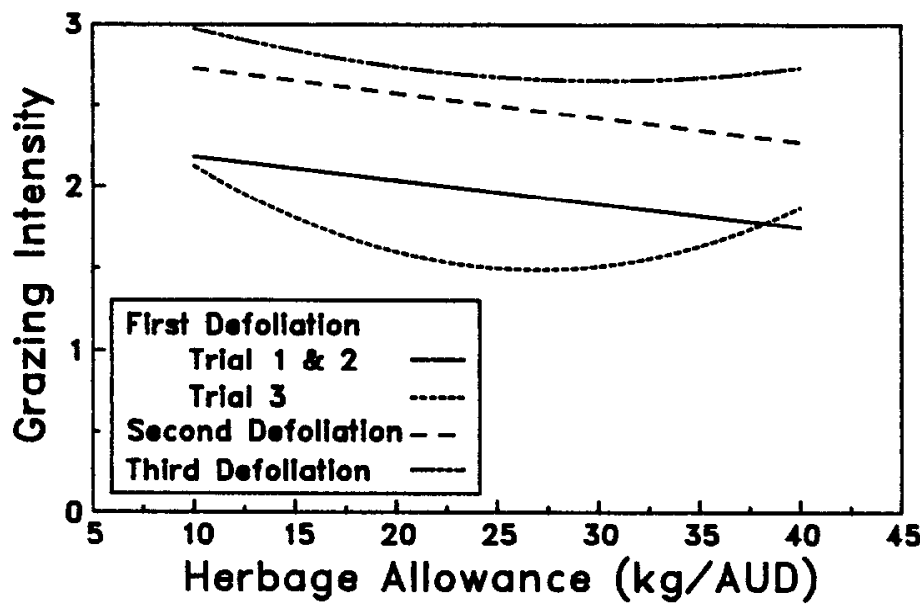

Fig. 6. Defoliation intensity averaged across species at the first, second, or third defoliation of individual tillers as affected by herbage allowance. Intensity scale: 0 = undefoliated, 1 = light, 2 = moderate, 3 = severe. All regressions were significant $(P<0.05)$. For the first defoliation, lines for Trials 1 and 2 were statistically equivalent to each other but different from Trial 3. There was no trial $\times$ herbage allowance interaction for the second and third defoliation.

moderate for the first defoliation; moderate to severe for the second defoliation; and severe for the third defoliation. Intensity

Table 6. Defoliation intensity based on leaf area removal for 3 species for the first, second, or third grazing of individual tillers.

\begin{tabular}{|c|c|c|c|c|c|}
\hline \multirow[b]{3}{*}{ Species } & \multicolumn{3}{|c|}{ First defoliation } & \multirow{3}{*}{$\begin{array}{l}\text { Second } \\
\text { defolia- } \\
\text { tion }\end{array}$} & \multirow{3}{*}{$\begin{array}{c}\text { Third } \\
\text { defolia } \\
\text { tion }\end{array}$} \\
\hline & \multicolumn{3}{|c|}{ Trial } & & \\
\hline & 1 & 2 & 3 & & \\
\hline Little bluestem & $2.0^{.23}$ & $1.6^{\mathrm{b}}$ & $1.6^{b}$ & $2.2^{b}$ & $2.7^{b}$ \\
\hline Big bluestem & $2.1^{\mathrm{a}}$ & $2.1^{*}$ & $1.9^{\circ}$ & $2.6^{a}$ & $2.8^{\mathrm{eb}}$ \\
\hline Indiangrass & $2.0^{2}$ & $2.1^{4}$ & $1.9^{\star}$ & $2.7^{\circ}$ & $2.9^{n}$ \\
\hline
\end{tabular}

ITrial $X$ species interaction not significant $(P>0.05$ ) for second and third defoliation. 2 Values with the same superscript within columns are not significantly different from each other, $P=0.05$.

${ }^{3}$ Defoliation intensity; $0=$ undefoliated, $1=$ light, $2=$ moderate, $3=$ severe. 
tended to increase as herbage allowance decreased for each defoliation. Little bluestem was usually grazed less intensely than indiangrass or big bluestem (Table 6) but there was no species $X$ herbage allowance interaction $(P>0.05)$. The goal of grazing any individual tiller at no greater than moderate intensity within a grazing period would be roughly equivalent to grazing any tiller no more than once. However, such a goal would require many tillers to go ungrazed.

\section{Conclusions}

The intensity and frequency of defoliation of individual grass tillers in tallgrass prairie increased as herbage allowance decreased or the time of livestock presence increased. Such results are not surprising and have been reported from several previous studies (Briske and Stuth 1982, Curll and Wilkins 1982, Hart and Balla 1982, Brown and Stuth 1984). These relationships gain practical significance when compared among species and viewed within the context of specific grazing management schemes.

Grazing systems with $\mathbf{8}$ or more pastures would most closely approximate the range of variables used in this study. For such systems, defoliation intensity within individual grazing periods would be moderate on the most palatable species when current guidelines for rest periods under short duration grazing are followed (Savory 1988). Selectivity among forage species would be little effected until herbage allowance was reduced below $25 \mathrm{~kg}$ $\mathrm{AUD}^{-1}$. Thirty-two pastures would be required to maintain herbage allowance within this range for the entire growing season under the conditions of this study. Selectivity between highly palatable species (indiangrass and big bluestem) and moderately palatable species (little bluestem) would still be noticeable even if herbage allowance was reduced to $10 \mathrm{~kg} \mathrm{AUD}^{-1}$.

It would not appear possible to defoliate all tillers of a given species a single time within a grazing period. The maximum percentage of tillers defoliated once was $50-80 \%$ in most cases. Regrazing had also begun to occur by the time this peak was reached. If all tillers within a species cannot be defoliated a single time, it is clear that all tillers within the plant community cannot be defoliated a single time.

The concept of a single defoliation within a grazing period still has merit because that single defoliation would result in a moderate amount of leaf area removal for the defoliated tiller. This would presumably favor rapid recovery from the defoliation. The goal of grazing any individual tiller no more than once is probably achievable and would be similar to a goal of no greater than moderate intensity utilization on any individual tiller. This would not be equivalent to grazing all tillers once. Many tillers would remain ungrazed but few or none would be severely grazed. Such a situation would, in essence, be the high performance grazing (HPG) system discussed by Booysen and Tainton (1978).

\section{Literature Cited}

Allison, C.D., M.M. Kothmann, and L.R. Rittenhouse. 1982. Efficiency of forage harvest by grazing cattle. J. Range Manage. 35:351-354.

Burthram, G.T., and S.A. Grant. 1984. Defoliation of ryegrass-dominated swards by sheep. Grass and Forage Sci. 39:211-219.
Briske, D.D., and J.W. Stuth. 1982. Tiller defoliation in a moderate and heavy grazing regime. J. Range Manage. 35:511-514.

Brown, J.R., and J.W. Stuth. 1984. The probability of individual tillers being grazed in a short duration grazing system. p. 197-203. In: Proc. Forage and Grassl. Conf., Houston, Texas, Amer. Forage and Grassl. Counc.

Booysen, P.D.V., and N.M. Tainton. 1978. Grassland management: principles and practices in South Africa, p. 551-554. In: Proc. Ist Int. Range Congr. D.N. Hyder (ed.), Soc. Range Manage. Denver, Colo.

Curll, M.L., and R.J. Wilkins. 1982. Frequency and severity of defoliation of grass and clover by sheep at different stocking rates. Grass and Forage Sci. 37:291-297.

Denny, R.P., and D.L. Barnes. 1977. Trials of multi-paddock grazing systems on veld 3. A comparison of six grazing procedures at two stocking rates. Rhod. J. Agr. Res. 15:129-142.

Gammon, D.M., and B.R. Roberts. 1978. Patterns of defoliation during continuous and rotational grazing of the Matopos Sandveld of Rhodesia. 1. Selectivity of grazing. Rhod. J. Agr. Res. 16:117-131.

Gammon, D.M., and B.R. Roberts. 1980. Aspects of defoliation during short duration grazing of the Matopos Sandveld of Zimbabwe. Zimbabwe J. Agr. Res. 18:29-38.

Gammon, D.M. 1984. An appraisal of short duration grazing as a method of veld management. Zimbabwe J. Agr. Res. 81:59-64.

Hart, R.H. 1989. SMART: a simple model to assess range technology. J. Range Manage. 42:421-424.

Hart, R.H., and E.F. Balla. 1982. Forage production and removal from western and crested wheatgrass pasture under grazing. J. Range Manage. 35:362-366.

Heitschmidt, R.K., S.L. Dowhower, and J.W. Walker. 1987a. 14- vs. 42-paddock rotational grazing: aboveground biomass dynamics, forage production, and harvest efficiency. J. Range Manage. 40:216-223.

Heitschmidt, R.K., S.L. Dowhower, and J.W. Walker. 1987b. 14 vs. 42-paddock rotational grazing: forage quality. J. Range Manage. 40:315-317.

Hodgson, J., and J.H. Ollerenshaw. 1969. Frequency and severity of defoliation of individual tillers in set stocked swards. J. Brit. Grassl. Soc. 24:226-234.

Hodgson, J. 1979. Nomenclature and definitions in grazing studies. Grass and Forage Sci. 34:11-18.

Holmes, W. (ed.). 1980. Grass its production and utilization. Blackwell Scientific Publication.

Kothmann, M.M. 1984. Concepts and principles underlying grazing systems: A discussant paper. p. 903-916 In: Nat. Res. Counc. - Nat. Acad. Sci. Developing strategies for rangeland management. Westview Press Inc. Boulder, Colo.

Norton, B.E., and P.S. Johnson. 1983. Pattern of defoliation by cattle grazing crested wheatgrass pastures. p. 462-464. In: Proc. XVI Int. Grassl. Congr. J. Allen Smith and Virgil W. Hays (eds.). Westview Press Inc. Boulder, Colo.

Pierson, F.B., and D.L. Scarnecchia. 1987. Defoliation of intermediate wheatgrass under seasonal and short duration grazing. J. Range Manage. 40:228-232.

Ralphs, M.H., M.M. Kothmann, and L.B. Merrill. 1986. Cattle and sheep diets under short duration grazing. J. Range Manage. 39:217-223.

Reece, P.E. 1986. Short duration grazing research and case studies in Nebraska. p. 39-71. In: J.A. Tiedeman (ed.). Short Duration Grazing. Coop. Ext. Washington State Univ., Pullman.

Savory, A. 1988. Holistic resource management. Island Press, Washington, D.C.

Tallowin, J.R.B., J.H.H. Williams, and R.V. Large. 1986. Some consequences of imposing different continuous grazing pressures in the spring of sward morphology, herbage quality, and the performance of young beef cattle. J. Agr. Sci. 106:129-139. 